\title{
Marble Filler: Does It Retard the Dissolution of Cement Constituents?
}

\author{
Ibrahim Messaoudene and Raoul Jauberthie \\ Civil Engeneering and Mechanical Laboratory, INSA—20, avenue des Buttes de Coësmes, CS 70839, 35708 Rennes, France
}

Correspondence should be addressed to Raoul Jauberthie, raoul.jauberthie@insa-rennes.fr

Received 13 April 2011; Accepted 24 May 2011

Academic Editors: E. Burkel and I. Lancellotti

Copyright ( $) 2011$ I. Messaoudene and R. Jauberthie. This is an open access article distributed under the Creative Commons Attribution License, which permits unrestricted use, distribution, and reproduction in any medium, provided the original work is properly cited.

\begin{abstract}
We showed In previous studies, that partial substitution of Portland cement with fillers from industrial by-products, slag and marble, have enabled the development of new hydraulic cements (ternary or quaternary) with a good mechanical performance, in addition to their economic and ecological benefits. This paper examines the influence of partial Portland cement replacement (CEM-I) with marble filler and other mineral additions on physicochemical properties of cement paste. A rapid preliminary test, the $\mathrm{pH}$ measurement of a binder suspension, reveals that marble powder lowers the $\mathrm{pH}$ of the cement. The solutions were stirred for 24 hours, the $\mathrm{pH}$ was recorded automatically. The hydration kinetics changed completely; it appears that even the slow setting phase disappears. To confirm the results, tests were carried out on mortars with partial substitution of Portland cement with fillers: measurement of shrinkage, swelling, and strength. The evolution of crystalline phases was monitored by XRD, and the portlandite content $\left(\mathrm{Ca}(\mathrm{OH})_{2}\right)$ at 28 days was determined indirectly by thermal gravimetric analysis and differential thermal analysis (TGA and DTA). The characterization methods indicate that marble filler retards various cement constituents from passing into solution.
\end{abstract}

\section{Introduction}

Marble is a metamorphic rock resulting from the transformation of a pure limestone. The purity of the marble is responsible for its colour and appearance: it is white if the limestone is composed solely of calcite $\left(100 \% \mathrm{CaCO}_{3}\right)$. Marble is used for construction and decoration; marble is durable, has a noble appearance, and is consequently in great demand. A large quantity of powder is generated during the cutting process. This waste product is used to replace limestone in cement production; it does not significantly alter concrete characteristics and also reduces the landfill impact of the waste material.

To reduce energy consumption and $\mathrm{CO}_{2}$ emissions and increase production, cement manufacturers use mineral additives such as slag, pozzolana, and limestone [1]. It is within this context that experimental studies have been carried out on the physicochemical properties of a binder, derived from the partial replacement of Portland cement (CEM-I) with marble powder, also from the replacement of Portland cement and a mixture of mineral additions.
The use of marble powder (MF) as a cement replacement has recently been the object of several research projects. Agarwal and Gulati [2] showed that the presence of marble powder in the cement matrix improves the early age compressive strength. Topçu et al. [3] studied the application of marble powder filler in self-compacting concrete; the workability of concrete is not affected by marble powder addition, but strength decreases with high marble powder contents $\left(200 \mathrm{~kg} / \mathrm{m}^{3}\right)$. A significant increase in strength is observed by the incorporation of crushed brick (22\%) in addition to marble powder [4]. According to other authors, the incorporation of $8 \%$ marble powder resulted in a reduction of mortar strengths.

\section{Preparation of the Binder Mixes}

Seven binders were prepared with a $10 \%$ marble filler cement replacement. The mineral additions are from Algeria: granulated slag (El-Hadjar steelworks), volcanic pozzolan (Beni-SAF), and marble dust from an industrial unit in Bordj Bou Arreridj. The mineralogical and chemical analysis 


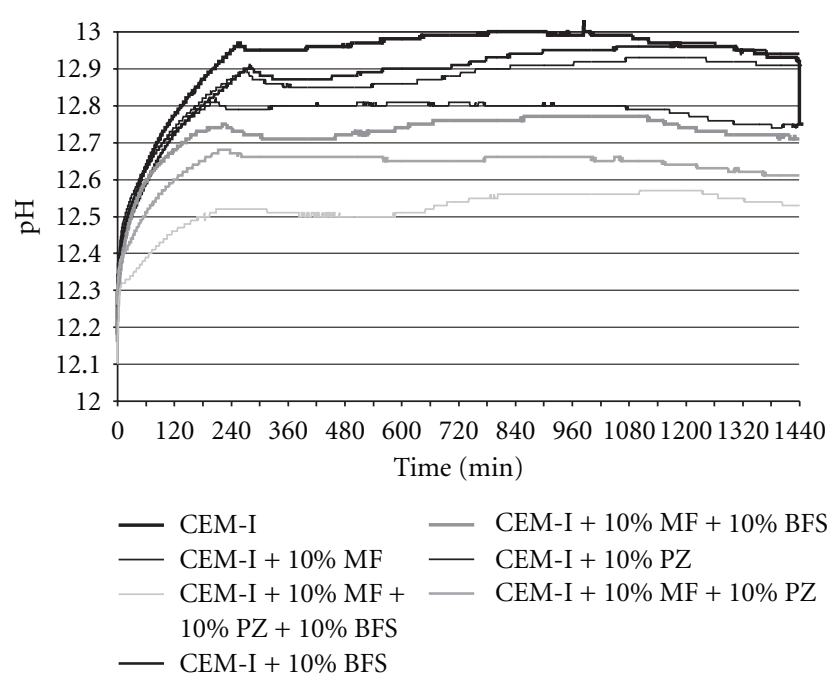

FIgURE 1: $\mathrm{pH}$ of the cementitious suspension ( $24 \mathrm{~h})$.

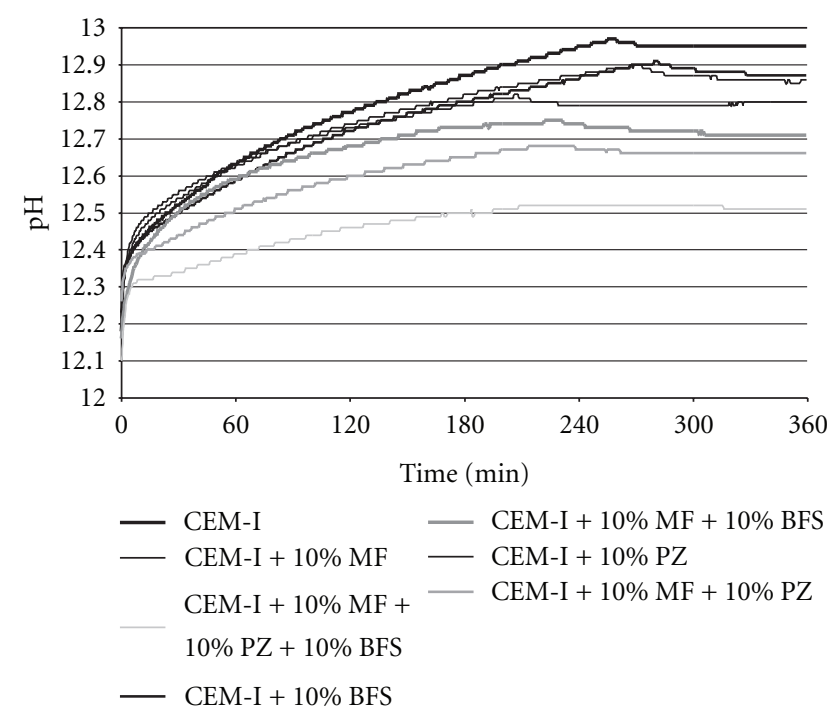

FIGURE 2: $\mathrm{pH}$ of the cementitious suspension (rapid setting phase).

of these products has already been published [5-7]. The cement used is a CEMI 52.5 (LAFARGE-France), its chemical and mineralogical compositions are presented in Table 1. The mineral additions have been crushed to a particle size less than $1 \mathrm{~mm}$ before being crushed in a vibratory disc mill and sieved to $80 \mu \mathrm{m}$; they are then thoroughly mixed with cement, the binder was quartered and prepared in the proportions set out in Table 2.

\section{Reaction in Solution: pH-Metrie}

Twenty grams of cement were mixed in a glass container with $100 \mathrm{ml}$ of demineralised water; a $\mathrm{pH}$ meter PHM220 was used to measure $\mathrm{pH}$ evolution of the solution. All measurements were made at a standard temperature of $20^{\circ} \mathrm{C}$. The solutions were continuously stirred for 24 hours and the $\mathrm{pH}$ measurement carried out automatically. Figure 1

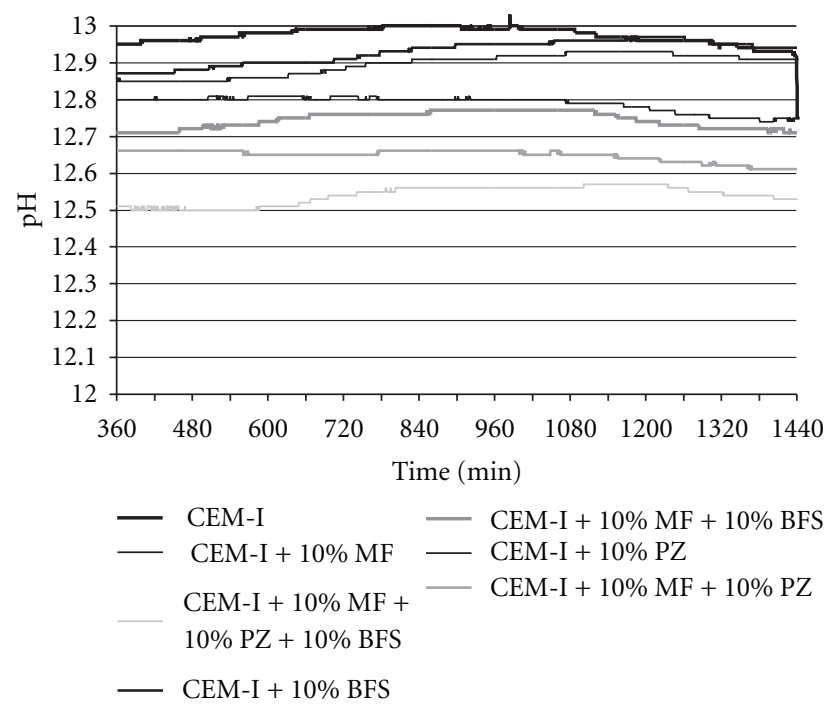

FIGURE 3: $\mathrm{pH}$ of the cementitious suspension (slow setting phase).

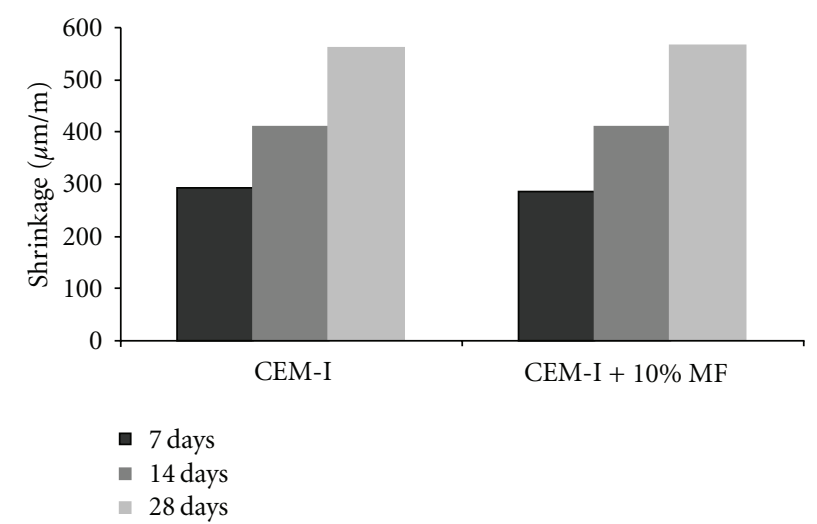

FIGURE 4: Influence of marble filler on mortar shrinkage.

shows the $\mathrm{pH}$ of the cement hydration suspension over 24 hours.

During the rapid setting phase (Figure 2), marble powder decreases the $\mathrm{pH}$ of the cement and cement with pozzolan or slag additions. It should be noted that the rapid setting period starts when the electrical conductivity of the solution is at a maximum. The increase in conductivity is due to the growth of ion concentration and mobility of ions dissolved in water $\left(\mathrm{Ca}^{2+}, \mathrm{OH}^{-}, \mathrm{SO}_{4}{ }^{2-}, \mathrm{Na}^{+}, \mathrm{K}^{+}\right)[8]$. Table 3 shows the values of $\mathrm{pH}_{\max }$ measured during the rapid setting phase. This peak relates to the super saturation peak and in the presence of marble the peak occurs earlier and with a reduced $\mathrm{pH}$; with the introduction of $10 \%$ marble powder this time difference is about $1 \mathrm{~h}$ (Table 3 ).

After approximately $6 \mathrm{~h}$, the hydration progressively slows down (slow setting phase) which continues for several hours. The $\mathrm{pH}$ of cement without marble filler addition continues to increase, reaching a maximum value after about 20 hours of hydration. The $\mathrm{pH}$ increases more rapidly in the case of cement without marble filler addition. The $\mathrm{pH}$ then gradually decreases until stabilization, this decrease in $\mathrm{pH}$ is 
TABLE 1: Chemical and mineralogical composition of cement CEM-I (\% by weight).

\begin{tabular}{|c|c|c|c|c|c|c|c|c|c|c|c|}
\hline $\mathrm{SiO}_{2}$ & $\mathrm{Al}_{2} \mathrm{O}_{3}$ & $\mathrm{Fe}_{2} \mathrm{O}_{3}$ & $\mathrm{CaO}$ & $\mathrm{MgO}$ & $\mathrm{SO}_{3}$ & $\mathrm{~K}_{2} \mathrm{O}$ & $\mathrm{Na}_{2} \mathrm{O}$ & $\mathrm{C}_{3} \mathrm{~S}$ & $\mathrm{C}_{2} \mathrm{~S}$ & $\mathrm{C}_{3} \mathrm{~A}$ & $\mathrm{C}_{4} \mathrm{AF}$ \\
\hline 22.40 & 2.96 & 2.33 & 66.60 & 0.95 & 2.13 & 0.15 & 0.10 & 65.30 & 18.60 & 4.35 & 7.14 \\
\hline
\end{tabular}

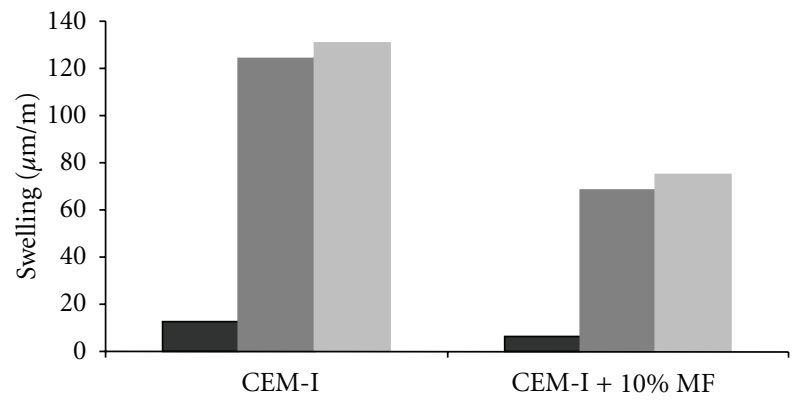

- 7 days

14 days

28 days

FIGURE 5: Influence of marble filler on mortar swelling.

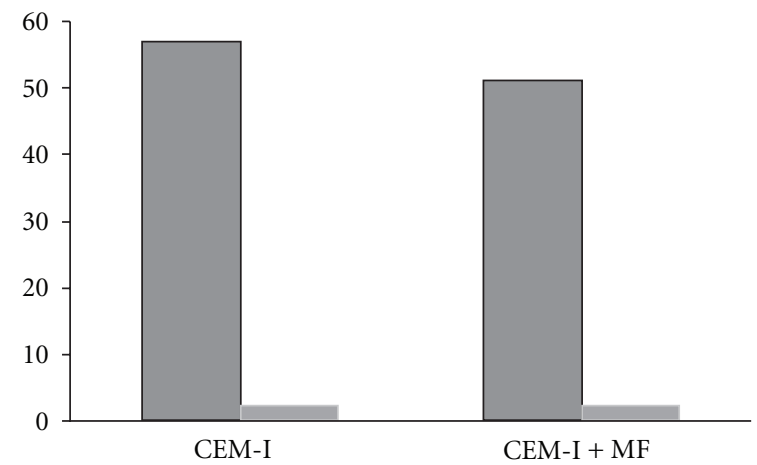

$\square$ Compressive strength $\mathrm{MPa}$

Inensity

\begin{tabular}{|l|c|c|}
\cline { 2 - 3 } \multicolumn{1}{c|}{} & CEM-I & CEM-I + MF \\
\hline $\begin{array}{c}\text { a Compressive strength } \\
\mathrm{MPa}\end{array}$ & 56.9 & 50.96 \\
\hline Density & 2.3 & 2.3 \\
\hline
\end{tabular}

Figure 6: Compressive strength and density of the mortars.

due to the decrease in conductivity due to the formation and accumulation of cement hydrates (ettringite, portlandite, $\mathrm{CSH}$ ); this reduction results from the decrease in the number of ions $[9,10]$.

The pozzolanic effect explains the changes in $\mathrm{pH}$ : during hydration the cement releases portlandite ions $\left(\mathrm{Ca}^{++}\right.$ and $\mathrm{OH}^{-}$) and then, gradually, the pozzolan and/or slag capture(s) the $\mathrm{Ca}^{++}$ions to form CSH or aluminates. The hydration reaction that occurs between Portland cement and cementitious additions is much slower. The results obtained

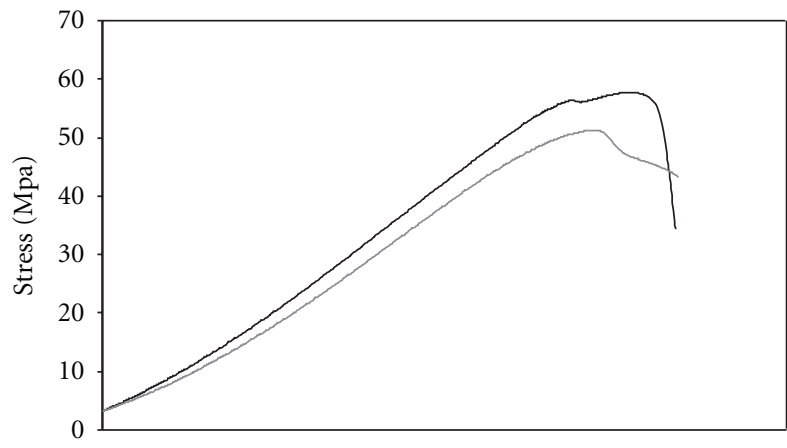

- CEM-I

- CEM-I + MF

Figure 7: Compressive stress strain curves.

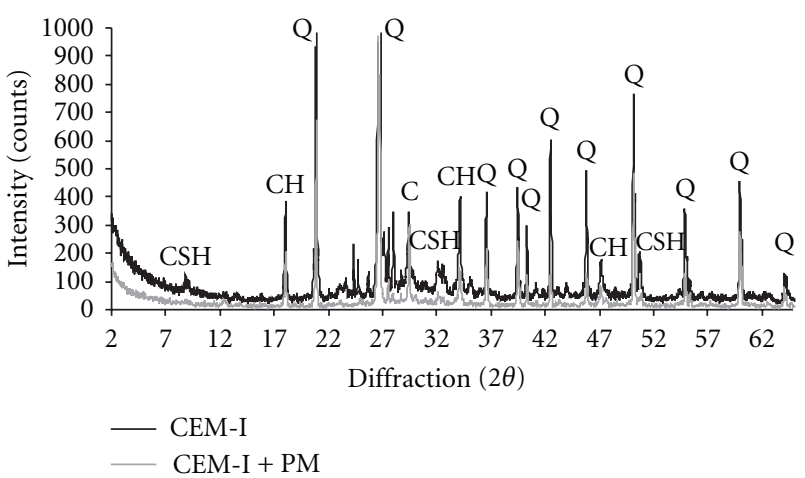

Figure 8: X-ray diffractogram of the mortars $\left(\mathrm{k}_{\alpha} \mathrm{Cu}\right)$.

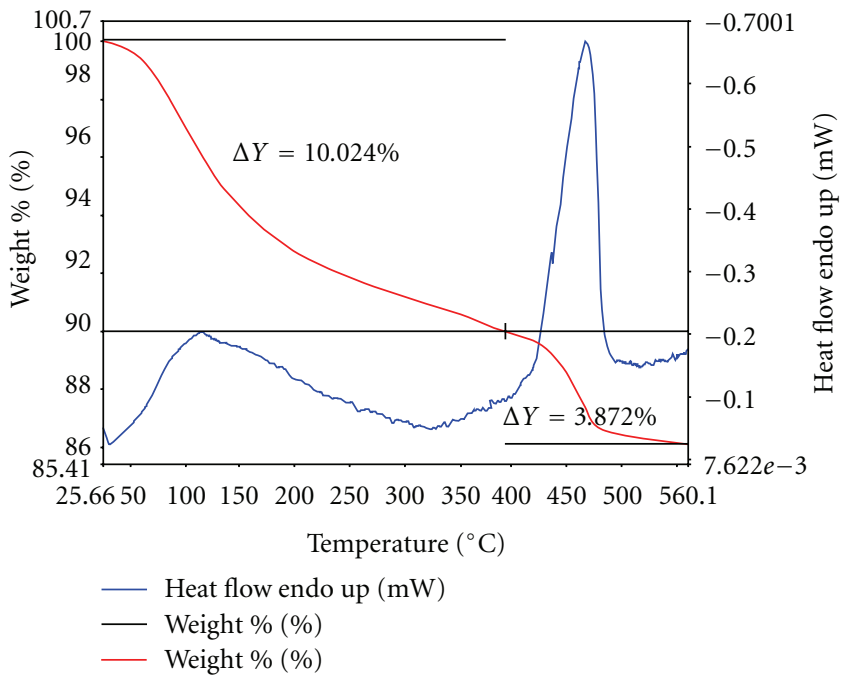

FIgURE 9: GTA and DTA of powdered Mortar 1. 


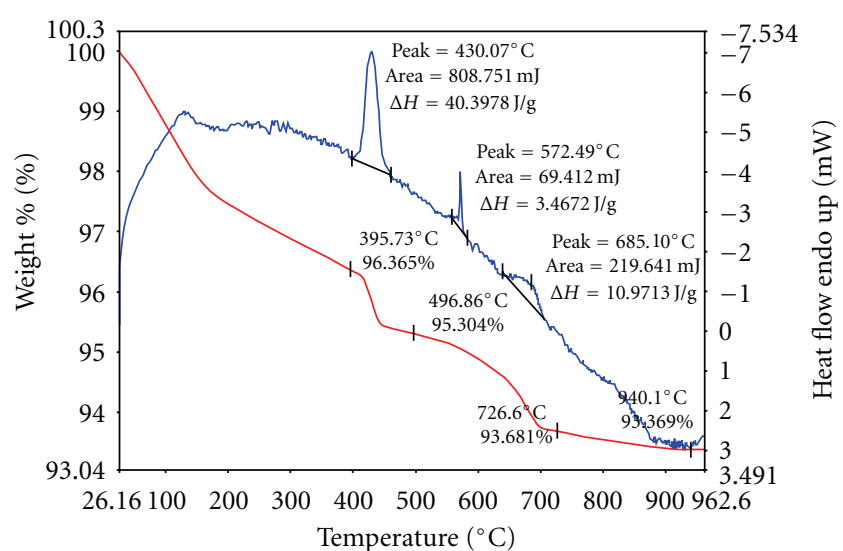

- Heat flow endo up (mW)

_ Heat flow endo up (mW)

— Weight \% (\%)

Figure 10: GTA and DTA of powdered Mortar 2.

TABle 2: Composition of binder mixes (\% by weight).

\begin{tabular}{lcccc}
\hline Mix & CEM-I & Pouzzolane (PZ) & Slag (BFS) & Marble filler (MF) \\
\hline 1 & 100 & 0 & 0 & 0 \\
2 & 90 & 0 & 0 & 10 \\
3 & 90 & 0 & 10 & 0 \\
4 & 90 & 10 & 0 & 0 \\
5 & 80 & 0 & 10 & 10 \\
6 & 80 & 10 & 0 & 10 \\
7 & 70 & 10 & 10 & 10 \\
\hline
\end{tabular}

TABLE 3: $\mathrm{pH}_{\max }$ during the rapid setting phase.

\begin{tabular}{lcc}
\hline Cementitious solution & $\mathrm{pH}_{\max }$ & Time (min) \\
\hline CEM-I 52.5 & 12.97 & 255 \\
90\% CEM-I + 10\% MF & 12.82 & 205 \\
90\% CEM-I + 10\% BFS & 12.91 & 280 \\
80\% CEM-I + 10\% BFS + 10\% MF & 12.75 & 223 \\
$90 \%$ CEM-I + 10\% PZ & 12.90 & 270 \\
80\% CEM-I + 10\% PZ + 10\% MF & 12.68 & 215 \\
$70 \%$ CEM-I + 10\% PZ + 10\% BFS + 10\% MF & 12.52 & 210 \\
\hline
\end{tabular}

(Figure 3) show that marble powder slows the dissolution of cement constituents; in effect the hydration time to reach a maximum $\mathrm{pH}$ is decreased. It appears that hydration is stopped for cement with marble filler addition (CEMI + MF): the slow setting phase has become a dormant phase. Table 4 shows the hydration time during the slow setting phase reaching a maximum $\mathrm{pH}$ and $\mathrm{pH}$ values after 24 hours.

\section{Tests on Mortar}

Two mortars were studied in these tests: Mortar 1 (reference) with CEM-I binder and Mortar 2 with the cement binder plus powdered marble: 90\% CEM-I + 10\% MF. The mortar is made in accordance with EN 196-1, (normal mortar: standard sand, water/binder $=0.5$, and cement $/$ sand $=1 / 3$ ).
TABLE 4: $\mathrm{pH}$ after $24 \mathrm{~h}$ hydration.

\begin{tabular}{lccc}
\hline Cementitious solution & $\begin{array}{c}\text { Time } \\
(\mathrm{min})\end{array}$ & $\mathrm{pH}_{\max }$ & $\begin{array}{c}\mathrm{pH} \\
(24 \mathrm{~h})\end{array}$ \\
\hline CEM-I 52.5 & 788 & 13.00 & 12.93 \\
90\% CEM-I + 10\% MF & 330 & 12.80 & 12.75 \\
90\% CEM-I + 10\% BFS & 1190 & 12.97 & 12.93 \\
80\% CEM-I + 10\% BFS + 10\% MF & 860 & 12.77 & 12.71 \\
90\% CEM-I + 10\% PZ & 1080 & 12.93 & 12.91 \\
80\% CEM-I + 10\% PZ + 10\% MF & 780 & 12.66 & 12.61 \\
70\% CEM-I + 10\% PZ + 10\% BFS + & 1100 & 12.57 & 12.53 \\
10\% MF & & &
\end{tabular}

TABLe 5: Area under the load deflection curve.

\begin{tabular}{ccc}
\hline & Mortar 1 & Mortar 2 \\
\hline Area $(\mathrm{kN} \cdot \mathrm{mm})$ & 54 & 49 \\
\hline
\end{tabular}

The size of the specimens used is $4 \times 4 \times 16 \mathrm{~cm}^{3}$. The samples are struck after 24 hours and cured (99\% relative humidity, $20^{\circ} \mathrm{C}$ ) for 28 days.

4.1. Measurement of Shrinkage and Swelling. This study involves the measurement of shrinkage and swelling of mortar specimens resulting from the cementitious binder. The tests are carried out in accordance with the standard NFP15-433. Sample lengths are noted at various times (7, 14 , and 28 days), the variation in length of $4 \times 4 \times 16 \mathrm{~cm}^{3}$ specimens, relative to its length at the time striking, that is, 24 hours after the preparation of specimens. From the results obtained (Figures 4 and 5), it can be seen that both cementitious binders cause virtually the same shrinkage at all ages. However, the sample swelling seen with CEM-I binder is higher than that with the binder containing $10 \%$ marble filler.

4.2. Compressive Strength. Figure 6 presents the average 28 day compressive strength and density of the two mortars. Despite having the same density, the strength of CEMI mortar is slightly higher than the mortar with $10 \%$ marble filler (strength decreased by about 10\%). This can be explained by the low reactivity of marble. This said, the strength is above $50 \mathrm{MPa}$ strength.

The energy dissipated before the failure is characterized by the area under the load deflection curve (Table 5); the sample with marble powder addition (MF) shows decreased energy dissipation. This result correlates with mechanical strength results. A qualitative comparison of stiffness of the two stress strains curves (Figure 7) also shows that the elastic modulus is slightly reduced for the mortar with marble powder addition.

\section{X-Ray Diffraction Analysis}

Figure 8 shows the X-ray diffraction patterns of mortars at 28 day; Mortar 1 with CEMI and Mortar 2 with CEMI + $10 \%$ marble powder addition. The analysis was carried out 
TABLE 6: Intensity of peaks (counts) corresponding to portlandite.

\begin{tabular}{lcc}
\hline Distance between the plates $\left(\mathrm{d}_{\mathrm{kkl}}\right) \AA$ & Mortar 1 & Mortar 2 \\
\hline 4,90 & 340,47 & 194,71 \\
2,62 & 330,47 & 133,44 \\
1,92 & 137,89 & 63,03 \\
\hline
\end{tabular}

TABLE 7: Quantity of portlandite in the mortar (\% by weight).

\begin{tabular}{lcc}
\hline Type of mortar & Mortar 1 & Mortar 2 \\
\hline $\mathrm{Ca}(\mathrm{OH})_{2}$ & 16 & 5 \\
\hline
\end{tabular}

on powdered mortar passing a 50 -microns sieve. The mineralogical composition is almost identical for the two mortars: the cement hydration products $(\mathrm{CSH}$ and $\mathrm{CH}$ ) and quartz (Q) which represents sand. The amount of portlandite $(\mathrm{CH})$, characterized by diffraction peaks (Table 6) is significantly reduced for the mortar with marble (CEM-I + MF). The diffractogramme shows that Mortar 2 has traces of calcite (C). The portlandite liberated in the hydration of the CEMI will, in the presence of $\mathrm{CO}_{2}$, increase the quantity of calcite. The latter could be the sum of the initial calcite marble and a second-generation germinated on the original calcite marble.

\section{Thermal Analysis}

The quantity of portlandite present in the mortars was quantified indirectly by thermal and differential gravimetric analysis (Figures 9 and 10). Thermal analysis was carried out over the range $25^{\circ} \mathrm{C}$ to $600^{\circ} \mathrm{C}$ for the reference mortar and $25^{\circ} \mathrm{C}$ to $950^{\circ} \mathrm{C}$ for Mortar 2 (the rate of temperature increase being $5^{\circ} \mathrm{C} / \mathrm{min}$ ). The mass loss around $430^{\circ} \mathrm{C}$ corresponds to the decomposition of portlandite following the reaction: $\mathrm{Ca}(\mathrm{OH})_{2} \rightarrow \mathrm{CaO}+\mathrm{H}_{2} \mathrm{O}$. The mass loss observed around $700^{\circ} \mathrm{C}$ (Mortar 2) corresponds to the decarbonation of calcite marble, which gives rise to the formation of quicklime $(\mathrm{CaO})$, following the reaction: $\mathrm{CaCO}_{3} \rightarrow \mathrm{CaO}+\mathrm{CO}_{2}$. The quantity of portlandite in Mortar 2 is reduced by $70 \%$ compared to the reference mortar (Mortar 1); this result is in agreement with the observed reduction of the portlandite peak on the XRD diffractogramme. The quantity of portlandite present in each type of mortar is set out in Table 7.

\section{Conclusion}

The $\mathrm{pH}$ of a solution of cement CEM-I, or cements with various pozzolanic additions, is reduced by the addition of marble powder filler; super saturation being reached faster in the presence of marble. Tests on mortar samples show that the shrinkage is not influenced by the presence of $10 \%$ marble filler; on the contrary, the swelling is reduced with marble addition. Addition of the marble powder filler does not change the density; however, the compressive strength decreases slightly.

The physicochemical analysis, XRD, and thermal analysis demonstrate that when a mix contains marble filler there is a decrease in the amount of portlandite. Mortar swelling, often attributed to portlandite, is lower due to the reduced portlandite content.

It is suggested that the marble fillers serve to germinate and fix the calcium released during hydration of the anhydrous cement compounds. The calcite crystals grow, the basicity of the medium decreases, the time to supersaturation is reduced, and the swelling of the mortar is reduced. This corroborates the observations of Govin et al. [11] who noted that "the calcite marble appears to introduce a higher carbonation of hydrated cement." Nevertheless, the mechanical strengths are slightly diminished by the incorporation of the marble powder but are still acceptable for current uses.

\section{References}

[1] S. Kenai, W. Soboyejo, and A. Soboyejo, "Some engineering properties of limestone concrete," Materials and Manufacturing Processes, vol. 19, no. 5, pp. 949-961, 2004.

[2] S. K. Agarwal and D. Gulati, "Utilization of industrial wastes and unprocessed micro-fillers for making cost effective mortars," Construction and Building Materials, vol. 20, no. 10, pp. 999-1004, 2006.

[3] I. B. Topçu, T. Bilir, and T. Uygunoğlu, "Effect of waste marble dust content as filler on properties of self-compacting concrete," Construction and Building Materials, vol. 23, no. 5, pp. 1947-1953, 2009.

[4] T. Kavas and A. Olgun, "Properties of cement and mortar incorporating marble dust and crushed brick," CeramicsSilikaty, vol. 52, no. 1, pp. 24-28, 2008.

[5] I. Messaoudene, R. Jauberthie, L. Molez, and A. Naceri, "Formulation, caractérisation des mortiers a base de sable de dune et de ciments aux ajouts minéraux locaux," in Proceedings of the Colloque E3D, Alexandrie, Egypte, Mars 2010.

[6] M. S. Mansour, M. T. Abadlia, R. Jauberthie, L. Molez, I. Messaoudene, and D. Rangeard, "Pouzzolanicité de la cendre volcanique de Béni Saf," in Proceedings of the Congrès International sur les Matériaux de l'Environnement, sidi Fredj, Alger, Algeria, Octobre 2010.

[7] I. Messaoudene, R. Jauberthie, L. Molez, D. Rangeard, and M. Mansour, "Mortiers à base de sable pliocène et de ciments aux ajouts : fillers industriels et cendres volcaniques," in Proceedings of the Congrès Matériaux, Nantes, France, Octobre 2010.

[8] M. S. Morsy, "Effect of temperature on electrical conductivity of blended cement pastes," Cement and Concrete Research, vol. 29, no. 4, pp. 603-606, 1999.

[9] H. Hodne and A. Saasen, "The effect of the cement zeta potential and slurry conductivity on the consistency of oilwell cement slurries," Cement and Concrete Research, vol. 30, no. 11, pp. 1767-1772, 2000.

[10] P. Barret and D. Bertrandie, "Fundamental hydration kinetic features of the major cement constituents: $\mathrm{Ca}_{3} \mathrm{SiO}_{5}$ and bCa1SiO ${ }_{4}$," Journal de Chimie Physique, vol. 11-12, pp. 765775, 1983.

[11] A. Govin, P. Grosseau, B. Guilhot, and R. Guyonnet, "Etude physico-chimique d'un composite ciment -bois Durant les premières heures d'hydratation," in Proceedings of the Journées Annuelles du Groupe Français de Céramique, Montpellier, France, 2003. 

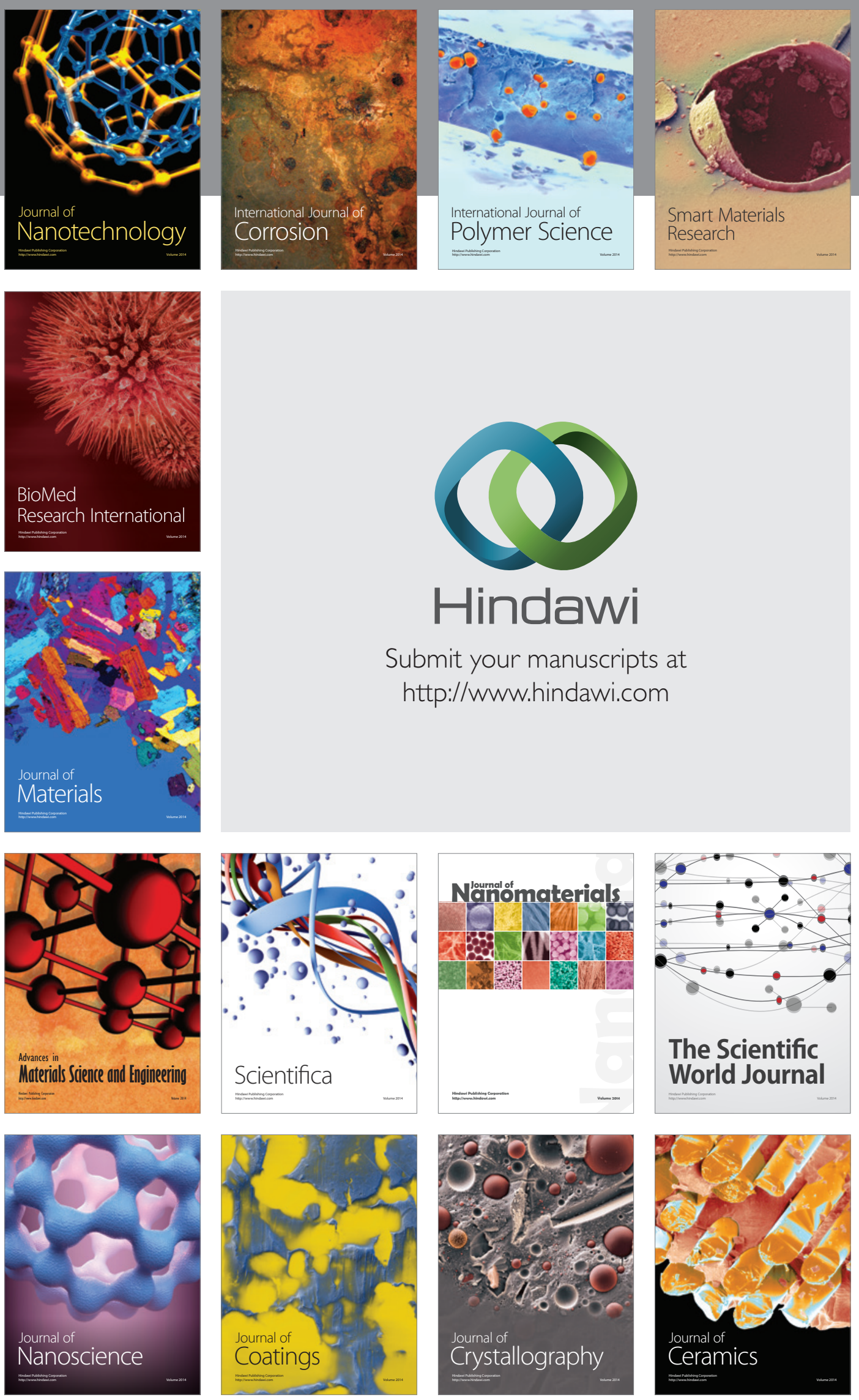

The Scientific World Journal

Submit your manuscripts at

http://www.hindawi.com

\section{World Journal}

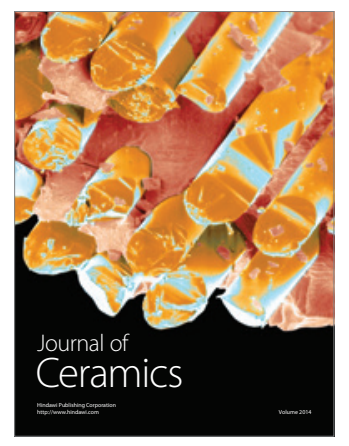

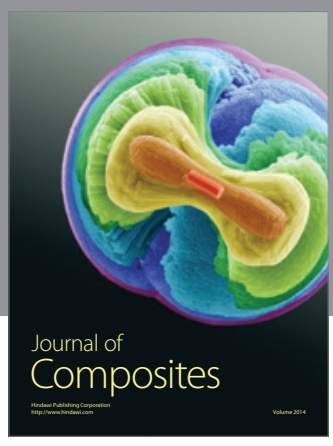
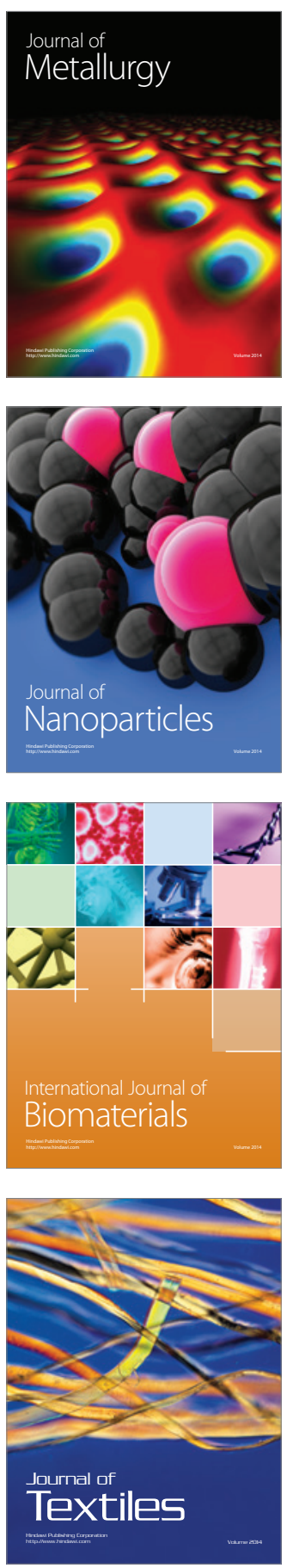